\title{
Curcumin: a natural substance with potential efficacy in Alzheimer's disease
}

\author{
This article was published in the following Dove Press journal: \\ Journal of Experimental Pharmacology \\ 2 May 2013 \\ Number of times this article has been viewed
}

\author{
Pamela E Potter \\ Department of Pharmacology, \\ Arizona College of Osteopathic \\ Medicine, Midwestern University, \\ Glendale, AZ, USA
}

Correspondence: Pamela E Potter Department of Pharmacology, Arizona College of Osteopathic Medicine, Midwestern University, 19555 N 59th

Ave, Glendale, AZ 8538I, USA

Email ppotte@midwestern.edu
Abstract: Curcumin is a component of turmeric, a spice used in many types of cooking. Epidemiological evidence suggesting that populations that eat food with a substantial amount of curcumin were at lower risk of Alzheimer's disease (AD) led to the idea that this compound might have a neuroprotective effect. Curcumin has substantial antioxidant and anti-inflammatory effects, and is being used as a potential preventative agent or treatment for many types of cancer. There is evidence to suggest that the addition of curcumin to cultured neuronal cells decreases brain inflammation and protects against $\beta$-amyloid-induced neurotoxicity. Curcumin also protects against toxicity when $\beta$-amyloid is administered to produce animal models of AD. Curcumin decreases $\beta$-amyloid formation from amyloid precursor protein, and also inhibits aggregation of $\beta$-amyloid into pleated sheets. Studies in transgenic mice with overproduction of $\beta$-amyloid demonstrate a neuroprotective effect of curcumin as well. Cognitive function was also improved in these animal models. Clinical trials of curcumin in AD have not been very promising. It is possible that this is due to poor oral bioavailability of curcumin in humans, and thus several approaches are being developed to improve delivery systems or to create analogs that will mimic the neuroprotective effects and easily reach the brain. The lack of efficacy of curcumin in humans with $\mathrm{AD}$ may also result from treating for too short a time or starting treatment too late in the course of the disease, where substantial neuronal death has already occurred and cannot be reversed. Curcumin may be beneficial in protecting against development or progression of $\mathrm{AD}$ if taken over the long term and started before symptoms of AD become apparent.

Keywords: curcumin, Alzheimer's disease, $\beta$-amyloid, neuroprotection

\section{Incidence of Alzheimer's disease (AD)}

$\mathrm{AD}$ is characterized by profound loss of short-term memory and impaired cognition, accompanied by neurodegeneration. Pathological changes including neuritic plaques and neurofibrillary tangles are hallmarks of the disease. ${ }^{1}$ Although the overall worldwide incidence of $\mathrm{AD}$ is $4.7 \%$, it is higher in Europe and the Americas at about $6.5 \%$. The incidence climbs from about $8 \%$ in those over age 65 years, to $45 \%$ in people older than 85 years. $^{2}$ Currently, 5.4 million Americans have AD, and it is the sixth leading cause of death. ${ }^{3}$ The total cost of AD in the US is estimated to be about $\$ 200$ billion. $^{3}$

\section{Etiology of AD}

The factors that precipitate neurodegeneration in AD are currently not understood. Although many neuronal populations degenerate as the disease progresses, ${ }^{4}$ loss of cholinergic neurons was one of the earliest neurochemical findings, suggesting a 
selective vulnerability of this population. ${ }^{5}$ Amyloid precursor protein (APP) is a membrane glycoprotein cleaved by three secretases, $\alpha, \beta$, and $\gamma$. Cleavage by $\alpha$-secretase generates a C-terminus fragment (C83) and soluble APP (sAPP), thought to be neurotrophic and neuroprotective. ${ }^{6,7}$ In contrast, sequential processing of APP by $\beta$-secretase (BACE-1) and $\gamma$ - secretase generates $\beta$-amyloid ${ }_{1-40}$ and $\beta$-amyloid ${ }_{1-42}$, widely thought to be neurotoxic. ${ }^{8}$

One of the components of $\gamma$-secretase is presenilin-1, which may be the catalytic core of the enzyme. ${ }^{9,10}$ Alterations in presenilin-1 are associated with some cases of early-onset familial AD. ${ }^{9}$ Presenilin-1 is a substrate for glycogen synthase

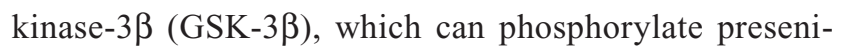
lin-1, thus modulating its activity. ${ }^{11}$ Increased expression of GSK-3 $\beta$ has also been associated with AD. ${ }^{12,13}$ Presenilin-2 mutations also increase the activity of $\gamma$-secretase. ${ }^{14,15}$ Mice with mutations in these genes have increased levels and deposition of $\beta$-amyloid, as well as deficits in learning and memory. ${ }^{16-18}$

The "amyloid cascade hypothesis," in which mutations in APP, presenilin-1, or presenilin-2 genes lead to increased production of $\beta$-amyloid, is now widely considered to contribute to the neurodegeneration seen in $\mathrm{AD} .{ }^{19}$ Mutations in these genes are linked to some forms of $\mathrm{AD}^{20}$ and although generally responsible for early-onset disease, they have also been reported in some patients with late-onset disease. ${ }^{21}$ Nevertheless, only about $5 \%$ of AD cases are caused by these mutations, and so it seems that there must be other factors that lead to an overproduction and deposition of $\beta$-amyloid. $\beta$-amyloid deposition leads to many toxic sequelae, including activation of microglia and astrocytes, oxidative stress, and possibly production of neurofibrillary tangles. ${ }^{22-25}$ The neurofibrillary tangles contain hyperphosphorylated tau, ${ }^{26,27}$ which, unlike normal tau protein, cannot stabilize microtubules. Thus, the microtubules become destabilized, affecting axonal function and transport. ${ }^{27,28} \beta$-amyloid also interferes with many neuronal processes, in particular those associated with signal transduction. ${ }^{29-31}$

Oxidative stress and inflammation have also been suggested to play a role in the neurodegeneration seen in $\mathrm{AD} .{ }^{32-35}$ Oxidative stress is thought to be an early, precipitating factor, ${ }^{36}$ and may contribute to generation of $\beta$-amyloid, either on its own, ${ }^{37,38}$ or in conjunction with inflammation. ${ }^{39-41}$ This has led to the suggestion that treatment with anti-inflammatory agents or drugs that reduce oxidative stress could be useful in the prevention or treatment of AD. ${ }^{42,43}$ Another contributor to the generation of $\beta$-amyloid is iron, which is found in higher than normal amounts in the brain of $\mathrm{AD}$ patients, and appears to accelerate translation of APP messenger ribonucleic acid and increase $\beta$-amyloid by stimulating an iron responsive element. ${ }^{44,45}$

\section{Current treatments}

The finding of massive degeneration of cholinergic neurons in $\mathrm{AD}$ led to the development of treatments targeted towards increasing cholinergic activity. ${ }^{46}$ Thus far, the most successful drugs have been cholinesterase inhibitors, which increase the amount of acetylcholine in the synaptic cleft, enhancing the function of the remaining cholinergic neurons. The cholinesterase inhibitors donepezil, galantamine, and rivastigmine are the current standard of treatment. ${ }^{47-50}$ The problem with cholinesterase inhibitors is that their effectiveness will decline as cholinergic neurons continue to degenerate. For this reason, a number of selective cholinergic agonists are currently in development. ${ }^{51}$ The other currently approved treatment for $\mathrm{AD}$ is the N-methyl-D-aspartic acid receptor antagonist memantine. ${ }^{48,52-54}$ There has been some evidence that both cholinesterase inhibitors and memantine may act to slow the course of AD progression by decreasing $\beta$-amyloid deposition or neurotoxicity, ${ }^{46,55-58}$ although this has been debated. ${ }^{58-62}$

Treatments directed at inflammation have been tested in patients with $\mathrm{AD}$. The observation that people with rheumatoid arthritis treated chronically with nonsteroidal

Table I The effects of curcumin on mechanisms involved in the degeneration in Alzheimer's disease

\begin{tabular}{|c|c|}
\hline $\begin{array}{l}\text { Mechanisms involved } \\
\text { in degeneration } \\
\text { in Alzheimer's disease }\end{array}$ & Effects of curcumin \\
\hline \multicolumn{2}{|l|}{$\beta$-amyloid } \\
\hline 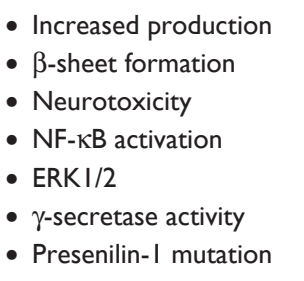 & $\begin{array}{l}\text { - Decrease in } \beta \text {-amyloid } 117 \\
\text { - Inhibition of sheet formation } 115,116 \\
\text { - Decrease neuronal toxicity } \\
\text { - Decrease NF-KB activation } \\
\text { - Decrease ERK-1/2 expression } \\
\text { - Inhibit } \gamma \text {-secretase }{ }^{119} \\
\text { - }{ }^{19} \\
\text { Modulate presenilin-I }{ }^{119}\end{array}$ \\
\hline \multicolumn{2}{|l|}{ Oxidative stress } \\
\hline 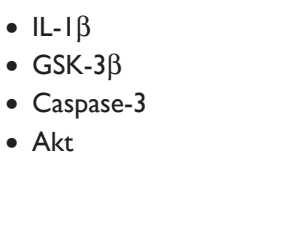 & $\begin{array}{l}\text { - Decrease IL-I } \beta^{123} \\
\text { - Decrease GSK-3} \beta^{112} \\
\text { - Prevent } \beta \text {-amyloid induced increase }{ }^{110} \\
\text { - Activate neuroprotective pathway }{ }^{110} \\
\text { - Iron chelation }{ }^{120} \\
\text { - Decrease phosphorylation }\end{array}$ \\
\hline $\begin{array}{l}\text { Other } \\
\text { - Iron } \\
\text { - Tau }\end{array}$ & \\
\hline
\end{tabular}

Abbreviations: ERK-I/2, extracellular signal-regulated kinase-I/2; GSK-3 $\beta$, glycogen synthase kinase-3 3 ; IL-I $\beta$, interleukin-I $\beta$; NF- $\mathrm{KB}$, nuclear factor-KB. 
anti-inflammatory drugs appeared to have a lower incidence of AD provided the groundwork for this hypothesis. ${ }^{63,64}$ This was supported by animal and cell culture studies indicating that treatment with nonsteroidal anti-inflammatory drugs could decrease levels of $\beta$-amyloid and tau, possibly by the inhibition of $\gamma$-secretase. ${ }^{65-67}$ Unfortunately, in spite of multiple trials, there has been little success with this treatment in older patients with AD, and in fact the ADAPT trial (AD Anti-inflammatory Prevention Trial) was stopped early due to the incidence of cardiovascular complications. ${ }^{68-71}$ However, there is evidence that treatment with nonsteroidal anti-inflammatory drugs may benefit some people, especially if they begin treatment when they are young. ${ }^{69,72,73}$ It is likely that anti-inflammatory treatments would be more useful if they were started before symptoms of the disease become apparent, as by that time the brain damage is substantial, and it may not be possible to reverse it.

It has been observed that the incidence of $\mathrm{AD}$ is quite low in India. ${ }^{7-76}$ This could be a result of genetics, as the incidence of the apolipoprotein-E4 (ApoE4) allele is also low in India. In one meta-analysis it was reported to be $34 \%$ ApoE $\varepsilon 4 /-$ and $4 \%$ ApoE $\varepsilon 4 / 4$ versus $56 \%$ and $11 \%$ in the US. ${ }^{77}$ Another study reported a frequency of 0.073 in a rural community in India versus 0.11 in a small Pennsylvania town. ${ }^{78}$ Although not completely correlated with the incidence of $\mathrm{AD}$, presence of the ApoE4 allele is considered a risk factor. ${ }^{77,79-81}$

In spite of the genetic differences, there is also a difference in the pathology of $\mathrm{AD}$ in India, with a decrease in $\beta$-amyloid ${ }_{1-42}$ in both normal controls and those patients who do develop $\mathrm{AD}$, as well as a decrease in hyperphosphorylated tau. ${ }^{82,83}$ It has been postulated that the reduced incidence or severity of AD in India might, beyond genetics, reflect differences in diet or environment. ${ }^{74}$ Indeed, people in India consume large amounts of curcumin, about $80-200 \mathrm{mg} / \mathrm{day},{ }^{84}$ which has long been known to have anti-inflammatory and antioxidant effects. ${ }^{85-88}$ Thus, it was suggested that curcumin might have a neuroprotective effect and be useful in the treatment or prevention of AD..$^{89-91}$

\section{Pharmacology of curcumin}

Curcumin (diferuloylmethane), a component of turmeric, comes from the herb Curcuma longa. It has been used for centuries as a spice in many foods, especially in Southeast Asia, and also as a coloring agent in condiments such as mustard. Toxicity studies have indicated that it is quite safe even in high doses (up to $12 \mathrm{~g}$ in humans). ${ }^{92,93}$ Its oral bioavailability, however, is poor, ${ }^{89,94,95}$ with low blood levels following oral administration and the majority of metabolites found in the feces. ${ }^{96}$ This could limit its usefulness as an oral therapeutic agent. Numerous studies are under way to develop delivery systems that will increase blood levels following administration of curcumin. ${ }^{97}$

Curcumin has been used in Ayurvedic medicine for numerous purposes, and there has recently been a lot of interest in its potential to treat many diseases. ${ }^{98}$ Its antibacterial effects were first described in $1949 .{ }^{99}$ In the last 10 years, interest in this compound for many uses has surged. Antifungal and antiviral properties have been described. ${ }^{100-102}$ Curcumin has antioxidant properties ${ }^{87,103,104}$ and anti-inflammatory properties. ${ }^{87,88,105}$ It is being proposed as a treatment or sensitizing agent for different types of cancer or to protect the body from the toxicity of certain agents used in cancer chemotherapy. ${ }^{98,106}$ It is thought to lower cholesterol and may regulate glucose and insulin levels, with potential for treatment of type II diabetes. ${ }^{98}$

The pharmacological effects of curcumin are mediated via actions on multiple sites, including transcription factors, enzymes, growth factors, neurotransmitter receptors, growth factor receptors, cytokine receptors, inflammatory mediators, and numerous protein kinases. ${ }^{98}$ In terms of potential effects in $\mathrm{AD}$, the ability to inhibit acetylcholinesterase, protect against $\beta$-amyloid toxicity and/or decrease its production, reduce the effects of oxidative stress, and decrease inflammation may be useful.

\section{Curcumin for AD}

Given the importance of $\beta$-amyloid accumulation in the pathogenesis of $\mathrm{AD}$, numerous in vitro and in vivo studies have examined the interaction of curcumin with $\beta$-amyloid. Several studies have investigated the dose-related neuroprotective effect of curcumin against $\beta$-amyloid-induced toxicity in cultured neuronal cells. ${ }^{107}$ Several mechanisms for this protective effect have been proposed. In both human neuroblastoma cells, blocking nuclear factor- $\kappa \mathrm{B}$ with curcumin was shown to prevent $\beta$-amyloid-induced cell death. ${ }^{30}$ Curcumin also reduced hypoxia-induced cell death in mouse hippocampal cells by inhibiting nuclear factor- $\kappa \mathrm{B}$-induced repression of peroxiredoxin-6. ${ }^{108}$ In a Human acute monocytic leukemia cell line (Sigma-Aldrich), curcumin was shown to reduce the $\beta$-amyloid-induced expression of the cytokines tumor necrosis factor- $\alpha$ and interleukin- $1 \beta$, as well as activation of mitogen-activated protein kinase and phosphorylation of extracellular signal-regulated kinase-1/2. ${ }^{109}$ In rat prefrontal cortex neurons, the $\beta$-amyloid-mediated increase in capsase- 3 was inhibited, and the neuroprotective pathway involving Akt was activated, by addition of curcumin. ${ }^{110}$ Again in rat cortical 
cells, curcumin maintained cell viability after exposure to $\beta$-amyloid and decreased markers of oxidative stress and levels of reactive oxygen species. ${ }^{111}$ Curcumin also appeared to reduce $\beta$-amyloid toxicity by decreasing the activity of GSK-3 $\beta$ and stimulating the protective Wnt/ $\beta$-catenin pathway in APPswe-transfected SY5Y cells. ${ }^{112}$ Thus, curcumin appears to act at many levels to ameliorate the neuronal damage that can be caused by inflammation, oxidative stress, or exposure to $\beta$-amyloid.

Curcumin may also affect the production and deposition of $\beta$-amyloid, long thought to be one of the triggers for neurodegeneration in AD. In both rat cortical neurons and in solution, curcumin produced a dose-dependent decrease in formation of fibrillary $\beta$-amyloid - $_{-40}$ and $\beta$-amyloid - $_{1-42}$ and also destabilized fibrils that had already formed, thus breaking up the $\beta$-sheet conformation seen in AD plaques. ${ }^{111,113-115}$ The mechanism for this effect is not known, but may involve binding to $\beta$-amyloid and preventing aggregation. ${ }^{113,114}$ Analogs of curcumin that maximize the inhibition of $\beta$-amyloid aggregation are being developed. ${ }^{116}$

Other lines of evidence suggest that curcumin exerts a benefit by decreasing levels of $\beta$-amyloid. Curcumin inhibited production of $\beta$-amyloid - $_{1-42}$ in cultured cells, and also decreased the level of the APP protein. ${ }^{117}$ It did not appear that processing of APP by BACE-1, an enzyme involved in production of $\beta$-amyloid, was involved as neither BACE-1 protein nor messenger ribonucleic acid levels were affected by curcumin; it was concluded that the effect must involve posttranslational processing of APP. ${ }^{117}$ Indeed, a subsequent study found that curcumin did not alter levels of mature APP, but did decrease immature and total APP. ${ }^{118}$ These authors suggested that inhibition of the APP maturation process could account for the observed decrease of both $\beta$-amyloid - $_{1-40}$ and $\beta$-amyloid ${ }_{1-42}$ by interrupting the pathway that leads to their production. ${ }^{118}$ Curcumin does appear to affect the activity of $\gamma$-secretase, by decreasing the expression of the catalytic component of the enzyme presenilin-1. ${ }^{119}$ This may result from inhibition of GSK-3 $\beta$, which normally phosphorylates presenilin-1 to stimulate $\gamma$-secretase. ${ }^{112,119}$ In addition to increasing levels of $\beta$-amyloid, activation of GSK-3 $\beta$ may also phosphorylate tau, allowing it to produce paired helical filaments. ${ }^{27}$ Another mechanism by which curcumin may decrease formation of $\beta$-amyloid would be through its ability to chelate iron, ${ }^{120}$ as increases in iron may facilitate production of $\beta$-amyloid. ${ }^{44}$ Curcumin decreases iron-induced neurotoxicity in primary cultures, ${ }^{121}$ and it has been proposed that the beneficial effect of curcumin in transgenic mice animal models of AD may be due, in part, to its effects on iron. ${ }^{122}$
Thus, curcumin may decrease production and deposition of $\beta$-amyloid through many different mechanisms, including alterations in the activity of $\gamma$-secretase and maturation of APP, inhibiting the activity of GSK-3 $\beta$ and tau production, and chelating iron. These actions are summarized in Table 1.

The studies described above were all done in vitro in either cultured cell lines or primary neuronal cell cultures. In vivo studies have also shown protective effects of curcumin in animal models of AD. The initial study was in the transgenic Tg2576 APPSw mouse model of AD, which contains a human mutation for $\mathrm{AD}$ and develops age-related pathology and behavioral changes similar to those in AD. ${ }^{16}$ Expression of interleukin-1, measures of oxidative damage, levels of $\beta$-amyloid, and plaque burden were all decreased following treatment of these animals with both high and low oral doses of curcumin for 6 months. ${ }^{123}$ The decreases were substantial at low doses (about 40\%), and similar to those which had been seen previously following treatment with the anti-inflammatory drug ibuprofen. ${ }^{124}$ These results were confirmed in a subsequent study, which also showed levels of curcumin in the brain following chronic oral treatment. ${ }^{125}$ Another model which has been studied involves the administration of ibotenic acid and $\beta$-amyloid $_{1-40}$ into rat brains to produce neurodegeneration and $\beta$-amyloid deposition, as well as memory loss. ${ }^{126}$ In this model, curcumin treatment for 20 days after the lesion, was found to improve performance in the Morris water maze, a test of short-term memory. ${ }^{126} \mathrm{~A}$ subsequent study indicated decreases in measures of inflammation and apoptosis, again supporting the neuroprotective effect of curcumin. ${ }^{127}$ Combining curcumin with omega-3 fatty acids increased its effectiveness at preventing tau phosphorylation and reducing memory impairment in 3xTg-AD transgenic mice. ${ }^{128}$

The promising results of these in vitro and in vivo animal studies have prompted tests of curcumin in humans (http://www.clinicaltrials.gov). In one, curcumin (1 g/day or $4 \mathrm{~g} /$ day) was combined with gingko for 6 months. Serum $\beta$-amyloid levels increased in the curcumin-treated group, suggesting loss from the brain, but there was no difference in mental status at the end of the trial. ${ }^{129}$ Curcumin could be detected in the blood 2 hours after treatment, suggesting that it had been absorbed, but levels were low. ${ }^{129}$ In a 24-week trial of patients with mild to moderate $A D$, no improvement was seen in the curcumin-treated $(2 \mathrm{~g}$ /day and $4 \mathrm{~g} /$ day doses) groups. ${ }^{130,131}$ The main side effect was gastrointestinal symptoms, but again the blood levels were low, suggesting that bioavailability was problematic. Other trials currently in progress include one combining a larger dose of curcumin with BioPerine ${ }^{\circledR}$ (Sabinsa Corporation, 
NJ, USA; an ingredient of black pepper thought to improve absorption of curcumin) and another using Longvida ${ }^{\circledR}$, (Verdure Sciences, IN, USA) a curcumin formulation thought to have better bioavailability. ${ }^{132,133}$ There have been no reports as yet from these studies.

\section{Future directions}

One of the reasons suggested for the lack of beneficial results of curcumin in $\mathrm{AD}$ clinical trials has been the inability to produce sufficient brain levels following oral absorption. ${ }^{134}$ It has been repeatedly shown that curcumin has poor water solubility and poor oral bioavailability, and that much of an administered dose is excreted in the feces. ${ }^{91,95,135,136}$ For this reason, there are a number of new formulations being developed which are hoped will improve the bioavailability and delivery of curcumin. ${ }^{137}$ These include curcumin analogs that mimic the active site of the compound, ${ }^{138}$ as well as analogs that mimic the curcumin anti-amyloid effect combined with an anticholinesterase effect. ${ }^{139}$ Solid lipid particle complexes and carrier systems $s^{140-146}$ and nanoparticle preparations ${ }^{137,147-151}$ are also being developed, as well as water soluble conjugates. ${ }^{153}$ A nanoparticle preparation has been shown to provide higher blood levels and was effective in Tg2576 transgenic mice. ${ }^{154}$ Much of this research has been spurred on by the potential for curcumin as an anticancer drug, but the benefits of finding better drug delivery systems will also be useful in potential treatment of AD.

Another possible reason that the clinical trials with curcumin have not shown any striking benefit is that they have been too short. When curcumin is administered to a transgenic mouse or a rat with toxin-induced neuronal damage, it may lead to disruption of $\beta$-amyloid deposition and even reverse some of the behavioral effects. However, in humans, $\mathrm{AD}$ progresses over a period of many years, and by the time symptoms are seen, there is extensive neuronal damage. ${ }^{155,156}$ Similar results have occurred with the $\beta$-amyloid vaccine, $\beta$-amyloid antibody treatment, and $\gamma$-secretase inhibitors, which were effective in transgenic mice, but did not improve cognitive function in patients who were already symptomatic for AD. ${ }^{157-164}$ For this reason, a treatment that may be neuroprotective should be initiated early to slow and prevent the damage from occurring, or if it has begun, to prevent it from progressing as rapidly. ${ }^{157}$ Thus, curcumin may have a role as a protective agent rather than a reversal agent, and it may benefit from being combined with other compounds, such as resveratrol, piperine, or epigallocatechin gallate from green tea, that have been shown to exert neuroprotective effects or that may enhance the effectiveness of curcumin. ${ }^{90,165,166}$

\section{Disclosure}

The author reports no conflicts of interest in this work.

\section{References}

1. Price DL, Sisodia SS, Gandy SE. Amyloid $\beta$ amyloidosis in Alzheimer's disease. Curr Opin Neurol. 1995;8(4):268-274.

2. Hebert LE, Wilson RS, Gilley DW, et al. Decline of language among women and men with Alzheimer's disease. J Gerontol B Psychol Sci Soc Sci. 2000;55(6):P354-P360.

3. www.alz.org [homepage on the Internet]. Alzheimer's Disease Facts and Figures. Available from: http://www.alz.org/alzheimers_disease_ facts_and_figures.asp. Accessed April 8, 2013.

4. Palmer AM. Neurochemical studies of Alzheimer's disease. Neurodegeneration. 1996;5(4):381-391.

5. Bartus RT, Dean RL 3rd, Beer B, Lippa AS. The cholinergic hypothesis of geriatric memory dysfunction. Science. 1982;217(4558):408-414.

6. Hunt CE, Turner AJ. Cell biology, regulation and inhibition of $\beta$-secretase (BACE-1). FEBS J. 2009;276(7):1845-1859.

7. Lichtenthaler SF. $\alpha$-secretase in Alzheimer's disease: molecular identity, regulation and therapeutic potential. J Neurochem. 2011;116(1): $10-21$

8. Cole SL, Vassar R. The role of amyloid precursor protein processing by BACE1, the $\beta$-secretase, in Alzheimer disease pathophysiology. J Biol Chem. 2008;283(44):29621-29625.

9. Borchelt DR, Thinakaran G, Eckman CB, et al. Familial Alzheimer's disease-linked presenilin 1 variants elevate $A \beta 1-42 / 1-40$ ratio in vitro and in vivo. Neuron. 1996;17(5):1005-1013.

10. Wolfe MS. The $\gamma$-secretase complex: membrane-embedded proteolytic ensemble. Biochemistry. 2006;45(26):7931-7939.

11. Twomey C, McCarthy JV. Presenilin-1 is an unprimed glycogen synthase kinase-3ß substrate. FEBS Lett. 2006;580(17):4015-4020.

12. DaRocha-Souto B, Coma M, Perez-Nievas BG, et al. Activation of glycogen synthase kinase- $3 \beta$ mediates $\beta$-amyloid induced neuritic damage in Alzheimer's disease. Neurobiol Dis. 2012;45(1):425-437.

13. Pei JJ, Tanaka T, Tung YC, Braak E, Iqbal K, Grundke-Iqbal I. Distribution, levels, and activity of glycogen synthase kinase-3 in the Alzheimer disease brain. J Neuropathol Exp Neurol. 1997;56(1):70-78.

14. Toda T, Noda Y, Ito G, Maeda M, Shimizu T. Presenilin-2 mutation causes early amyloid accumulation and memory impairment in a transgenic mouse model of Alzheimer's disease. J Biomed Biotechnol. 2011;2011:617974.

15. Sawamura N, Morishima-Kawashima M, Waki H, et al. Mutant presenilin 2 transgenic mice. A large increase in the levels of A $\beta 42$ is presumably associated with the low density membrane domain that contains decreased levels of glycerophospholipids and sphingomyelin. J Biol Chem. 2000;275(36):27901-27908.

16. Hsiao K, Chapman P, Nilsen S, et al. Correlative memory deficits, $\mathrm{A} \beta$ elevation, and amyloid plaques in transgenic mice. Science. 1996;274(5284):99-102.

17. Westerman MA, Cooper-Blacketer D, Mariash A, et al. The relationship between $\mathrm{A} \beta$ and memory in the Tg2576 mouse model of Alzheimer's disease. J Neurosci. 2002;22(5):1858-1867.

18. Gordon MN, King DL, Diamond DM, et al. Correlation between cognitive deficits and A $\beta$ deposits in transgenic APP+PS1 mice. Neurobiol Aging. 2001;22(3):377-385.

19. Hardy J, Selkoe DJ. The amyloid hypothesis of Alzheimer's disease: progress and problems on the road to therapeutics. Science. 2002; 297(5580):353-356.

20. Goate A, Hardy J. Twenty years of Alzheimer's disease-causing mutations. J Neurochem. 2012;120(Suppl 1):3-8.

21. Cruchaga $C$, Haller $G$, Chakraverty $S$, et al. Rare variants in APP, PSEN1 and PSEN2 increase risk for AD in late-onset Alzheimer's disease families. PloS One. 2012;7(2):e31039.

22. Sisodia SS, Price DL. Role of the $\beta$-amyloid protein in Alzheimer's disease. FASEB J. 1995;9(5):366-370. 
23. Roher AE, Esh CL, Kokjohn TA, et al. Amyloid $\beta$ peptides in human plasma and tissues and their significance for Alzheimer's disease. Alzheimers Dement. 2009;5(1):18-29.

24. Davies L, Wolska B, Hilbich C, et al. A4 amyloid protein deposition and the diagnosis of Alzheimer's disease: prevalence in aged brains determined by immunocytochemistry compared with conventional neuropathologic techniques. Neurology. 1988;38(11):1688-1693.

25. Kar S, Quirion R. Amyloid $\beta$ peptides and central cholinergic neurons: functional interrelationship and relevance to Alzheimer's disease pathology. Prog Brain Res. 2004;145:261-274.

26. Kurt MA, Davies DC, Kidd M. Paired helical filament morphology varies with intracellular location in Alzheimer's disease brain. Neurosci Lett. 1997;239(1):41-44.

27. Ballatore C, Lee VM, Trojanowski JQ. Tau-mediated neurodegeneration in Alzheimer's disease and related disorders. Nat Rev Neurosci. 2007; 8(9):663-672.

28. Goedert M, Klug A, Crowther RA. Tau protein, the paired helical filament and Alzheimer's disease. J Alzheimers Dis. 2006;9(Suppl 3): 195-207.

29. Alberdi E, Sanchez-Gomez MV, Cavaliere F, et al. Amyloid $\beta$ oligomers induce $\mathrm{Ca} 2+$ dysregulation and neuronal death through activation of ionotropic glutamate receptors. Cell Calcium. 2010;47(3):264-272.

30. Kuner P, Schubenel R, Hertel C. $\beta$-amyloid binds to p57NTR and activates NFKB in human neuroblastoma cells. J Neurosci Res. 1998;54(6):798-804.

31. Strosznajder JB, Zambrzycka A, Kacprzak MD, Strosznajder RP. Amyloid $\beta$ peptide 25-35 modulates hydrolysis of phosphoinositides by membrane phospholipase(s) C of adult brain cortex. J Mol Neurosci. 1999;12(2):101-109.

32. Lee YJ, Han SB, Nam SY, Oh KW, Hong JT. Inflammation and Alzheimer's disease. Arch Pharm Res. 2010;33(10):1539-1556.

33. Cai Z, Zhao B, Ratka A. Oxidative stress and $\beta$-amyloid protein in Alzheimer's disease. Neuromolecular Med. 2011;13(4):223-250.

34. Akiyama H, Barger S, Barnum S, et al. Inflammation and Alzheimer's disease. Neurobiol Aging. 2000;21(3):383-421.

35. McGeer EG, McGeer PL. The importance of inflammatory mechanisms in Alzheimer disease. Exp Gerontol. 1998;33(5):371-378.

36. Nunomura A, Perry G, Aliev G, et al. Oxidative damage is the earliest event in Alzheimer disease. J Neuropathol Exp Neurol. 2001;60(8): 759-767.

37. Butterfield DA, Boyd-Kimball D. Amyloid $\beta$-peptide(1-42) contributes to the oxidative stress and neurodegeneration found in Alzheimer disease brain. Brain Pathol. 2004;14(4):426-432.

38. Christen Y. Oxidative stress and Alzheimer disease. Am J Clin Nutr. 2000;71(2):621S-629S.

39. Yao Y, Chinnici C, Tang H, Trojanowski JQ, Lee VM, Pratico D. Brain inflammation and oxidative stress in a transgenic mouse model of Alzheimer-like brain amyloidosis. J Neuroinflammation. 2004; $1(1): 21$.

40. Simpson JE, Ince PG, Haynes LJ, et al. Population variation in oxidative stress and astrocyte DNA damage in relation to Alzheimertype pathology in the ageing brain. Neuropathol Appl Neurobiol. 2010;36(1):25-40.

41. Agostinho P, Cunha RA, Oliveira C. Neuroinflammation, oxidative stress and the pathogenesis of Alzheimer's disease. Curr Pharm Des. 2010;16(25):2766-2778.

42. Bregman N, Karni A, Korczyn AD. Can treatment with nonsteroidal anti-inflammatory drugs protect from dementia? Arch Neurol. 2009;66(4):539-540.

43. McNaull BB, Todd S, McGuinness B, Passmore AP. Inflammation and anti-inflammatory strategies for Alzheimer's disease - a mini-review. Gerontology. 2010;56(1):3-14.

44. Cahill CM, Lahiri DK, Huang X, Rogers JT. Amyloid precursor protein and $\alpha$ synuclein translation, implications for iron and inflammation in neurodegenerative diseases. Biochim Biophys Acta. 2009;1790(7): $615-628$.
45. Cho HH, Cahill CM, Vanderburg CR, et al. Selective translational control of the Alzheimer amyloid precursor protein transcript by iron regulatory protein-1. J Biol Chem. 2010;285(41):31217-31232.

46. Fisher A. Cholinergic treatments with emphasis on $\mathrm{m} 1$ muscarinic agonists as potential disease-modifying agents for Alzheimer's disease. Neurotherapeutics. 2008;5(3):433-442.

47. Osborn GG, Saunders AV. Current treatments for patients with Alzheimer disease. J Am Osteopath Assoc. 2010;110(9 Suppl 8): S16-S26.

48. Atri A, Shaughnessy LW, Locascio JJ, Growdon JH. Long-term course and effectiveness of combination therapy in Alzheimer disease. Alzheimer Dis Assoc Disord. 2008;22(3):209-221.

49. Birks J. Cholinesterase inhibitors for Alzheimer's disease [review]. Cochrane Database Syst Rev. 2006;1:CD005593.

50. Hansen RA, Gartlehner G, Webb AP, Morgan LC, Moore CG, Jonas DE. Efficacy and safety of donepezil, galantamine, and rivastigmine for the treatment of Alzheimer's disease: a systematic review and meta-analysis. Clin Interv Aging. 2008;3(2):211-225.

51. Fisher A. Cholinergic modulation of amyloid precursor protein processing with emphasis on M1 muscarinic receptor: perspectives and challenges in treatment of Alzheimer's disease. J Neurochem. 2012;120(Suppl 1):22-33.

52. Herrmann N, Li A, Lanctot K. Memantine in dementia: a review of the current evidence. Expert Opin Pharmacother. 2011;12(5):787-800.

53. McShane R, Areosa Sastre A, Minakaran N. Memantine for dementia [review]. Cochrane Database Syst Rev. 2006;2:CD003154.

54. Molinuevo JL, Garcia-Gil V, Villar A. Memantine: an antiglutamatergic option for dementia. Am J Alzheimers Dis Other Demen. 2004;19(1): $10-18$.

55. Beach TG, Walker DG, Potter PE, Sue LI, Fisher A. Reduction of cerebrospinal fluid amyloid $\beta$ after systemic administration of M1 muscarinic agonists. Brain Res. 2001;905(1-2):220-223.

56. Farias GG, Godoy JA, Hernandez F, Avila J, Fisher A, Inestrosa NC. M1 muscarinic receptor activation protects neurons from $\beta$-amyloid toxicity. A role for Wnt signaling pathway. Neurobiol Dis. 2004;17(2):337-348.

57. Bordji K, Becerril-Ortega J, Nicole O, Buisson A. Activation of extrasynaptic, but not synaptic, NMDA receptors modifies amyloid precursor protein expression pattern and increases amyloid- $\beta$ production. J Neurosci. 2010;30(47):15927-15942.

58. Bordji K, Becerril-Ortega J, Buisson A. Synapses, NMDA receptor activity and neuronal A $\beta$ production in Alzheimer's disease. Rev Neurosci. 2011;22(3):285-294.

59. Golde TE. Disease modifying therapy for AD? J Neurochem. 2006; 99(3):689-707.

60. Munoz-Torrero D. Acetylcholinesterase inhibitors as disease-modifying therapies for Alzheimer's disease. Curr Med Chem. 2008;15(24): 2433-2455.

61. Beusterien KM, Thomas SK, Gause D, Kimel M, Arcona S, Mirski D. Impact of rivastigmine use on the risk of nursing home placement in a US sample. CNS Drugs. 2004;18(15):1143-1148.

62. Geldmacher DS, Provenzano G, McRae T, Mastey V, Ieni JR. Donepezil is associated with delayed nursing home placement in patients with Alzheimer's disease. J Am Geriatr Soc. 2003;51(7):937-944.

63. McGeer PL, Schulzer M, McGeer EG. Arthritis and anti-inflammatory agents as possible protective factors for Alzheimer's disease: a review of 17 epidemiologic studies. Neurology. 1996;47(2):425-432.

64. Sastre M, Gentleman SM. NSAIDs: how they work and their prospects as therapeutics in Alzheimer's disease. Front Aging Neurosci. 2010;2:20.

65. Abdul-Hay SO, Luo J, Ashghodom RT, Thatcher GR. NO-flurbiprofen reduces amyloid- $\beta$, is neuroprotective in cell culture, and enhances cognition in response to cholinergic blockade. J Neurochem. 2009;111(3): 766-776.

66. Lee RK, Wurtman RJ. Regulation of APP synthesis and secretion by neuroimmunophilin ligands and cyclooxygenase inhibitors. Ann NY Acad Sci. 2000;920:261-268. 
67. Tomita T. Secretase inhibitors and modulators for Alzheimer's disease treatment. Expert Rev Neurother. 2009;9(5):661-679.

68. Rogers J, Kirby LC, Hempelman SR, et al. Clinical trial of indomethacin in Alzheimer's disease. Neurology. 1993;43(8):1609-1611.

69. Intveld BA, Ruitenberg A, Hofman A, et al. Nonsteroidal antiinflammatory drugs and the risk of Alzheimer's disease. N Engl J Med. 2001;345(21):1515-1521.

70. Martin BK, Szekely C, Brandt J, et al; ADAPT Research Group. Cognitive function over time in the Alzheimer's Disease Antiinflammatory Prevention Trial (ADAPT): results of a randomized, controlled trial of naproxen and celecoxib. Arch Neurol. 2008;65(7): 896-905.

71. Meinert CL, McCaffrey LD, Breitner JC. ADAPT Research Group. Alzheimer's Disease Anti-inflammatory Prevention Trial: design, methods, and baseline results. Alzheimers Dement. 2009;5(2):93-104.

72. Hayden KM, Zandi PP, Khachaturian AS, et al. Does NSAID use modify cognitive trajectories in the elderly? The Cache County study. Neurology. 2007;69(3):275-282.

73. Etminan M, Gill S, Samii A. Effect of non-steroidal anti-inflammatory drugs on risk of Alzheimer's disease: systematic review and metaanalysis of observational studies. BMJ. 2003;327(7407):128.

74. Chandra V, Pandav R, Dodge HH, et al. Incidence of Alzheimer's disease in a rural community in India: the Indo-US study. Neurology. 2001;57(6):985-989.

75. Shaji S, Bose S, Verghese A. Prevalence of dementia in an urban population in Kerala, India. Br J Psychiatry. 2005;186:136-140.

76. Vas CJ, Pinto C, Panikker D, et al. Prevalence of dementia in an urban Indian population. Int Psychogeriatr. 2001;13(4):439-450.

77. Ward A, Crean S, Mercaldi CJ, et al. Prevalence of apolipoprotein E4 genotype and homozygotes (APOE e4/4) among patients diagnosed with Alzheimer's disease: a systematic review and meta-analysis. $\mathrm{Neu}$ roepidemiology. 2012;38(1):1-17.

78. Ganguli M, Chandra V, Kamboh MI, et al. Apolipoprotein E polymorphism and Alzheimer disease: the Indo-US cross-national dementia study. Arch Neurol. 2000;57(6):824-830.

79. Altamura C, Squitti R, Pasqualetti P, et al. What is the relationship among atherosclerosis markers, apolipoprotein E polymorphism and dementia? Eur J Neurol. 2007;14(6):679-682.

80. Andreasen N, Hesse C, Davidsson P, et al. Cerebrospinal fluid $\beta$-amyloid(1-42) in Alzheimer disease: differences between early- and late-onset Alzheimer disease and stability during the course of disease. Arch Neurol. 1999;56(6):673-680.

81. Ahn Jo S, Ahn K, Kim JH, et al. ApoE- $\varepsilon$ 4-dependent association of the choline acetyltransferase gene polymorphisms $(2384 \mathrm{G}>\mathrm{A}$ and 1882G > A) with Alzheimer's disease. Clin Chim Acta. 2006;368(1-2): $179-182$.

82. Kandimalla RJ, S P, Bk B, et al. Cerebrospinal fluid profile of amyloid $\beta 42$ (A $\beta 42)$, hTau and ubiquitin in North Indian Alzheimer's disease patients. Neurosci Lett. 2011;487(2):134-138.

83. Subramanian S, Sandhyarani B, Shree AND, et al. Lower levels of cerebrospinal fluid amyloid $\beta(\mathrm{A} \beta)$ in non-demented Indian controls. Neurosci Lett. 2006;407(2):121-123.

84. Commandeur JN, Vermeulen NP. Cytotoxicity and cytoprotective activities of natural compounds. The case of curcumin. Xenobiotica. 1996;26(7):667-680.

85. Joe B, Lokesh BR. Role of capsaicin, curcumin and dietary n-3 fatty acids in lowering the generation of reactive oxygen species in rat peritoneal macrophages. Biochim Biophys Acta. 1994;1224(2): 255-263.

86. Reddy AC, Lokesh BR. Studies on spice principles as antioxidants in the inhibition of lipid peroxidation of rat liver microsomes. Mol Cell Biochem. 1992;111(1-2):117-124.

87. Menon VP, Sudheer AR. Antioxidant and anti-inflammatory properties of curcumin. Adv Exp Med Biol. 2007;595:105-125.

88. Rao TS, Basu N, Siddiqui HH. Anti-inflammatory activity of curcumin analogues. Indian J Med Res. 1982;75:574-578.
89. Aggarwal BB, Sung B. Pharmacological basis for the role of curcumin in chronic diseases: an age-old spice with modern targets. Trends Pharmacol Sci. 2009;30(2):85-94.

90. Frautschy SA, Cole GM. Why pleiotropic interventions are needed for Alzheimer's disease. Mol Neurobiol. 2010;41(2-3):392-409.

91. Ringman JM, Frautschy SA, Cole GM, Masterman DL, Cummings JL. A potential role of the curry spice curcumin in Alzheimer's disease. Curr Alzheimer Res. 2005;2(2):131-136.

92. Wahlstrom B, Blennow G. A study on the fate of curcumin in the rat. Acta Pharmacol Toxicol (Copenh). 1978;43(2):86-92.

93. Lao CD, Ruffin MT 4th, Normolle D, et al. Dose escalation of a curcuminoid formulation. BMC Complement Altern Med. 2006;6:10.

94. Goel A, Kunnumakkara AB, Aggarwal BB. Curcumin as "curecumin" from kitchen to clinic. Biochem Pharmacol. 2008;75(4):787-809.

95. Anand P, Kunnumakkara AB, Newman RA, Aggarwal BB. Bioavailability of curcumin: problems and promises. Mol Pharm. 2007;4(6):807-818.

96. Sharma RA, McLelland HR, Hill KA, et al. Pharmacodynamic and pharmacokinetic study of oral Curcuma extract in patients with colorectal cancer. Clin Cancer Res. 2001;7(7):1894-1900.

97. Darvesh AS, Carroll RT, Bishayee A, Novotny NA, Geldenhuys WJ, Van der Schyf CJ. Curcumin and neurodegenerative diseases: a perspective. Expert Opin Invest Drugs. 2012;21(8):1123-1140.

98. Gupta SC, Patchva S, Koh W, Aggarwal BB. Discovery of curcumin, a component of golden spice, and its miraculous biological activities. Clin Exp Pharm Physiol. 2012;39(3):283-299.

99. Schraufstatter E, Bernt H. Antibacterial action of curcumin and related compounds. Nature. 1949;164(4167):456.

100. Dovigo LN, Pavarina AC, Carmello JC, Machado AL, Brunetti IL, Bagnato VS. Susceptibility of clinical isolates of Candida to photodynamic effects of curcumin. Lasers Surg Med. 2011;43(9): 927-934.

101. Neelofar K, Shreaz S, Rimple B, Muralidhar S, Nikhat M, Khan LA. Curcumin as a promising anticandidal of clinical interest. Can J Microbiol. 2011;57(3):204-210.

102. Zandi K, Ramedani E, Mohammadi K, et al. Evaluation of antiviral activities of curcumin derivatives against HSV-1 in Vero cell line. Nat Prod Commun. 2010;5(12):1935-1938.

103. Kolodziejczyk J, Olas B, Saluk-Juszczak J, Wachowicz B. Antioxidative properties of curcumin in the protection of blood platelets against oxidative stress in vitro. Platelets. 2011;22(4): 270-276

104. Sandur SK, Ichikawa H, Pandey MK, et al. Role of pro-oxidants and antioxidants in the anti-inflammatory and apoptotic effects of curcumin (diferuloylmethane). Free Radic Biol Med. 2007;43(4):568-580.

105. Sandur SK, Pandey MK, Sung B, et al. Curcumin, demethoxycurcumin, bisdemethoxycurcumin, tetrahydrocurcumin and turmerones differentially regulate anti-inflammatory and anti-proliferative responses through a ROS-independent mechanism. Carcinogenesis. 2007;28(8) 1765-1773.

106. Shen L, Ji HF. The pharmacology of curcumin: is it the degradation products? Trends Mol Med. 2012;18(3):138-144.

107. Kim DS, Park SY, Kim JK. Curcuminoids from Curcuma longa L. (Zingiberaceae) that protect $\mathrm{PC} 12$ rat pheochromocytoma and normal human umbilical vein endothelial cells from $\beta \mathrm{A}(1-42)$ insult. Neurosci Lett. 2001;303(1):57-61.

108. Chhunchha B, Fatma N, Kubo E, Rai P, Singh SP, Singh DP. Curcumin abates hypoxia-induced oxidative stress based-ER stress-mediated cell death in mouse hippocampal cells (HT22) by controlling Prdx6

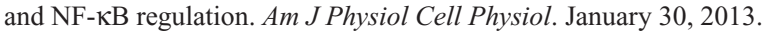
[Epub ahead of print.]

109. Giri RK, Rajagopal V, Kalra VK. Curcumin, the active constituent of turmeric, inhibits amyloid peptide-induced cytochemokine gene expression and CCR5-mediated chemotaxis of THP-1 monocytes by modulating early growth response-1 transcription factor. J Neurochem. 2004;91(5):1199-1210. 
110. Qin XY, Cheng Y, Yu LC. Potential protection of curcumin against intracellular amyloid $\beta$-induced toxicity in cultured rat prefrontal cortical neurons. Neurosci Lett. 2010;480(1):21-24.

111. Huang HC, Chang P, Dai XL, Jiang ZF. Protective effects of curcumin on amyloid- $\beta$-induced neuronal oxidative damage. Neurochem Res. 2012;37(7):1584-1597.

112. Zhang X, Yin WK, Shi XD, Li Y. Curcumin activates Wnt/ $\beta$-catenin signaling pathway through inhibiting the activity of GSK-3 $\beta$ in APPswe transfected SY5Y cells. Eur J Pharm Sci. 2011;42(5):540-546.

113. Ono K, Hasegawa K, Naiki H, Yamada M. Curcumin has potent anti-amyloidogenic effects for Alzheimer's $\beta$-amyloid fibrils in vitro. J Neurosci Res. 2004;75(6):742-750.

114. Yang F, Lim GP, Begum AN, et al. Curcumin inhibits formation of amyloid $\beta$ oligomers and fibrils, binds plaques, and reduces amyloid in vivo. J Biol Chem. 2005;280(7):5892-5901.

115. Zhao LN, Chiu SW, Benoit J, Chew LY, Mu Y. The effect of curcumin on the stability of A $\beta$ dimers. J Phys Chem B. 2012;116(25): 7428-7435.

116. Orlando RA, Gonzales AM, Royer RE, Deck LM, Vander Jagt DL. A chemical analog of curcumin as an improved inhibitor of amyloid A $\beta$ oligomerization. PloS One. 2012;7(3):e31869.

117. Liu H, Li Z, Qiu D, Gu Q, Lei Q, Mao L. The inhibitory effects of different curcuminoids on $\beta$-amyloid protein, $\beta$-amyloid precursor protein and $\beta$-site amyloid precursor protein cleaving enzyme 1 in swAPP HEK293 cells. Neurosci Lett. 2010;485(2):83-88.

118. Zhang C, Browne A, Child D, Tanzi RE. Curcumin decreases amyloid- $\beta$ peptide levels by attenuating the maturation of amyloid- $\beta$ precursor protein. J Biol Chem. 2010;285(37):28472-28480.

119. Zhang X, Zhang HM, Si L, Li Y. Curcumin mediates presenilin-1 activity to reduce $\beta$-amyloid production in a model of Alzheimer's disease. Pharmacol Rep. 2011;63(5):1101-1108.

120. Jiao Y, Wilkinson J 4th, Di X, et al. Curcumin, a cancer chemopreventive and chemotherapeutic agent, is a biologically active iron chelator. Blood. 2009;113(2):462-469.

121. Dai MC, Zhong ZH, Sun YH, et al. Curcumin protects against iron induced neurotoxicity in primary cortical neurons by attenuating necroptosis. Neurosci Lett. 2013;536:41-46.

122. Baum L, NgA. Curcumin interaction with copper and iron suggests one possible mechanism of action in Alzheimer's disease animal models. J Alzheimers Dis. 2004;6(4):367-377.

123. Lim GP, Chu T, Yang F, Beech W, Frautschy SA, Cole GM. The curry spice curcumin reduces oxidative damage and amyloid pathology in an Alzheimer transgenic mouse. J Neurosci. 2001;21(21): 8370-8377.

124. Lim GP, Yang F, Chu T, et al. Ibuprofen effects on Alzheimer pathology and open field activity in APPsw transgenic mice. Neurobiol Aging. 2001;22(6):983-991.

125. Begum AN, Jones MR, Lim GP, et al. Curcumin structure-function, bioavailability, and efficacy in models of neuroinflammation and Alzheimer's disease. J Pharmacol Exp Ther. 2008;326(1): 196-208.

126. Ahmed T, Enam SA, Gilani AH. Curcuminoids enhance memory in an amyloid-infused rat model of Alzheimer's disease. Neuroscience. 2010;169(3):1296-1306.

127. Ahmed T, Gilani AH. A comparative study of curcuminoids to measure their effect on inflammatory and apoptotic gene expression in an $\mathrm{A} \beta$ plus ibotenic acid-infused rat model of Alzheimer's disease. Brain Res. 2011;1400:1-18.

128. Ma QL, Yang F, Rosario ER, et al. $\beta$-amyloid oligomers induce phosphorylation of tau and inactivation of insulin receptor substrate via c-Jun N-terminal kinase signaling: suppression by omega-3 fatty acids and curcumin. J Neurosci. 2009;29(28):9078-9089.

129. Baum L, Lam CW, Cheung SK, et al. Six-month randomized, placebocontrolled, double-blind, pilot clinical trial of curcumin in patients with Alzheimer disease. J Clin Psychopharmacol. 2008;28(1):110-113.
130. Ringman JM, Frautschy SA, Teng E, et al. Oral curcumin for Alzheimer's disease: tolerability and efficacy in a 24-week randomized, double blind, placebo-controlled study. Alzheimers Res Ther. 2012;4(5):43.

131. Ringman JM, Cole GM, Teng E, et al. Oral curcumin for the treatment of mild-to-moderate Alzheimer's disease: tolerability and clinical and biomarker efficacy results of a placebo-controlled 24-week study. Alzheimers Dement. 2008;4(Suppl 4):T774.

132. www.clinicaltrials.gov [homepage on the Internet]. http://www.alz.org/ alzheimers_disease_facts_and_figures.asp Accessed April 8, 2013.

133. www.alzforum.org [homepage on the Internet]. Drugs in Clinical Trials. Available from: http://www.alzforum.org/drg/drc/detail. asp?id=137. Accessed April 8, 2013.

134. Mancuso C, Siciliano R, Barone E. Curcumin and Alzheimer disease: this marriage is not to be performed. J Biol Chem. 2011; 286(3):1e3.

135. Cheng AL, Hsu CH, Lin JK, et al. Phase I clinical trial of curcumin, a chemopreventive agent, in patients with high-risk or pre-malignant lesions. Anticancer Res. 2001;21(4B):2895-2900.

136. Shoba G, Joy D, Joseph T, Majeed M, Rajendran R, Srinivas PS. Influence of piperine on the pharmacokinetics of curcumin in animals and human volunteers. Planta Med. 1998;64(4):353-356.

137. Belkacemi A, Doggui S, Dao L, Ramassamy C. Challenges associated with curcumin therapy in Alzheimer disease. Expert Rev Mol Med. 2011;13:e34.

138. Chen SY, Chen Y, LiYP, et al. Design, synthesis, and biological evaluation of curcumin analogues as multifunctional agents for the treatment of Alzheimer's disease. Bioorg Med Chem. 2011;19(18): 5596-5604.

139. Bolognesi ML, Bartolini M, Tarozzi A, et al. Multitargeted drugs discovery: balancing anti-amyloid and anticholinesterase capacity in a single chemical entity. Bioorg Med Chem Lett. 2011;21(9): 2655-2658.

140. Dadhaniya P, Patel C, Muchhara J, et al. Safety assessment of a solid lipid curcumin particle preparation: acute and subchronic toxicity studies. Food Chem Toxicol. 2011;49(8):1834-1842.

141. Manju S, Sreenivasan K. Conjugation of curcumin onto hyaluronic acid enhances its aqueous solubility and stability. J Colloid Interface Sci. 2011;359(1):318-325.

142. Manju S, Sreenivasan K. Hollow microcapsules built by layer by layer assembly for the encapsulation and sustained release of curcumin. Colloids Surf B Biointerfaces. 2011;82(2):588-593.

143. Manju S, Sreenivasan K. Synthesis and characterization of a cytotoxic cationic polyvinylpyrrolidone-curcumin conjugate. J Pharm Sci. 2011;100(2):504-511.

144. Gupta NK, Dixit VK. Bioavailability enhancement of curcumin by complexation with phosphatidyl choline. J Pharm Sci. 2011;100(5): 1987-1995.

145. Setthacheewakul S, Mahattanadul S, Phadoongsombut N, Pichayakorn W, Wiwattanapatapee R. Development and evaluation of selfmicroemulsifying liquid and pellet formulations of curcumin, and absorption studies in rats. Eur J Pharm Biopharm. 2010;76(3):475-485.

146. Takahashi M, Uechi S, Takara K, Asikin Y, Wada K. Evaluation of an oral carrier system in rats: bioavailability and antioxidant properties of liposome-encapsulated curcumin. J Agric Food Chem . 2009;57(19): 9141-9146.

147. Manju S, Sreenivasan K. Gold nanoparticles generated and stabilized by water soluble curcumin-polymer conjugate: blood compatibility evaluation and targeted drug delivery onto cancer cells. J Colloid Interface Sci. 2012;368(1):144-151.

148. Ghosh D, Choudhury ST, Ghosh S, et al. Nanocapsulated curcumin: oral chemopreventive formulation against diethylnitrosamine induced hepatocellular carcinoma in rat. Chem Biol Interact. 2012;195(3): 206-214.

149. Ghosh M, Singh AT, Xu W, Sulchek T, Gordon LI, Ryan RO. Curcumin nanodisks: formulation and characterization. Nanomedicine. 2011;7(2):162-167. 
150. Shaikh J, Ankola DD, Beniwal V, Singh D, Kumar MN. Nanoparticle encapsulation improves oral bioavailability of curcumin by at least 9-fold when compared to curcumin administered with piperine as absorption enhancer. Eur J Pharm Sci. 2009;37(3-4):223-230.

151. Yallapu MM, Gupta BK, Jaggi M, Chauhan SC. Fabrication of curcumin encapsulated PLGA nanoparticles for improved therapeutic effects in metastatic cancer cells. J Colloid Interface Sci. 2010;351(1): 19-29.

152. Mohanty C, Sahoo SK. The in vitro stability and in vivo pharmacokinetics of curcumin prepared as an aqueous nanoparticulate formulation. Biomaterials. 2010;31(25):6597-6611.

153. Debnath S, Saloum D, Dolai S, et al. Dendrimer-curcumin conjugate: a water soluble and effective cytotoxic agent against breast cancer cell lines. Anticancer Agents Med Chem. January 24, 2013. [Epub ahead of print.]

154. Cheng KK, Yeung CF, Ho SW, Chow SF, Chow AH, Baum L. Highly stabilized curcumin nanoparticles tested in an in vitro blood-brain barrier model and in Alzheimer's disease Tg2576 mice. AAPS J. December 11, 2012. [Epub ahead of print.]

155. Dubois B, Feldman HH, Jacova C, et al. Revising the definition of Alzheimer's disease: a new lexicon. Lancet Neurol. 2010;9(11): 1118-1127.

156. Golde TE, Schneider LS, Koo EH. Anti-A $\beta$ therapeutics in Alzheimer's disease: the need for a paradigm shift. Neuron. 2011; 69(2):203-213.

157. Janus C, Pearson J, McLaurin J, et al. A $\beta$ peptide immunization reduces behavioural impairment and plaques in a model of Alzheimer's disease. Nature. 2000;408(6815):979-982.

158. Morgan D, Diamond DM, Gottschall PE, et al. A $\beta$ peptide vaccination prevents memory loss in an animal model of Alzheimer's disease. Nature. 2000;408(6815):982-985.
159. Nicoll JA, Wilkinson D, Holmes C, Steart P, Markham H, Weller RO. Neuropathology of human Alzheimer disease after immunization with amyloid- $\beta$ peptide: a case report. Nat Med. 2003;9(4):448-452.

160. Blennow K, Zetterberg H, Wei J, Liu E, Black R, Grundman M. Immunotherapy with bapineuzumab lowers CSF tau protein levels in patients with Alzheimer's disease. Alzheimers Dement. 2010;6(Suppl 4) S134-S135.

161. Laskowitz DT, Kolls BJ. A phase 2 multiple ascending dose trial of bapineuzumab in mild to moderate Alzheimer disease. Neurology. 2010;74(24):2026.

162. DeMattos RB, Racke MM, Gelfanova V, et al. Identification, characterization, and comparison of amino-terminally truncated $\mathrm{A} \beta_{42}$ peptides in Alzheimer's disease brain tissue and in plasma from Alzheimer's patients receiving solanezumab immunotherapy treatment. Alzheimers Dement. 2009;5(Suppl 4):P156-P157.

163. Bateman RJ, Siemers ER, Mawuenyega KG, et al. A $\gamma$-secretase inhibitor decreases amyloid- $\beta$ production in the central nervous system. Ann Neurol. 2009;66(1):48-54.

164. Eli Lilly and Company. Lilly halts development of semagacestat for Alzheimer's disease based on preliminary results of Phase III clinical trials [press release]. Indianapolis, IN: Eli Lilly and Company; 2012 [August 17]. Available from: http://newsroom.lilly.com/releasedetail. cfm?ReleaseID=499794. Accessed March 8, 2013.

165. Parachikova A, Green KN, Hendrix C, LaFerla FM. Formulation of a medical food cocktail for Alzheimer's disease: beneficial effects on cognition and neuropathology in a mouse model of the disease. PloS One. 2010;5(11):e14015.

166. Davinelli S, Sapere N, Zella D, Bracale R, Intrieri M, Scapagnini G. Pleiotropic protective effects of phytochemicals in Alzheimer's disease. Oxid Med Cell Longev. 2012;2012:386527.
Journal of Experimental Pharmacology

\section{Publish your work in this journal}

The Journal of Experimental Pharmacology is an international, peerreviewed, open access journal publishing original research, reports, reviews and commentaries on all areas of laboratory and experimental pharmacology. The manuscript management system is completely online and includes a very quick and fair peer-review system.

\section{Dovepress}

Visit http://www.dovepress.com/testimonials.php to read real quotes from published authors. 